\title{
KESENJANGAN GENDER DAN KESETARAAN KETENAGAKERJAAN: SEBUAH TINJAUAN
}

\author{
Suryono Efendi \\ Universitas Nasional \\ Email: suryono.efendi@yahoo.com
}

\begin{abstract}
Abstrak
Makalah ini berfokus pada Pemerataan Ketenagakerjaan dan berbagai sub-isu terkait dominasi laki-laki dalam organisasi, kelompok sasaran, kebijakan pemerintah, dan sistem kuota. Makalah ini mencoba untuk menjawab pertanyaan tentang apakah kesetaraan di tempat kaca hanyalah kata-kata manis yang tanpa makna" dan mengabaikan kekurangan perempuan karena komitmen organisasi untuk memajukan perempuan?. Jadi kesetaraan tempat kerja adalah kepedulian terhadap kemajuan yang semata-mata diimbangi dengan prestasi dan keterampilan, Terlebih lagi secara aktif mempromosikan perempuan dan kelompok minoritas yang layak tanpa memihak dan diskriminasi dalam bentuk apa pun. Ekuitas tempat kerja yang sempurna membuat organisasi menjadi tempat yang ideal untuk bekerja dan meningkatkan citra tanggung jawab sosial organisasi.
\end{abstract}

Kata Kunci: Kesenjangan Gender, Tempat kerja, Kesetaraan.

\section{Abstract}

The purpose of this article is to discuss Employment Equity and many sub-issues including male domination in organizations, target groups, government policies, and quota systems. This study attempts to address the topic of whether equality in the mirror is only "sweet words without meaning" that glosses over women's failings in the name of the organization's dedication to women's advancement. Thus, workplace equality is a concern for growth that is entirely balanced on the basis of merit and ability, as well as aggressively supporting good women and minorities without regard for bias or prejudice. Perfect workplace equity contributes to the organization's attractiveness as a place to work and strengthens the organization's image of social responsibility.

Keywords: Gender Gap, Workplace, Equality.

\section{A. PENDAHULUAN}

Saat ini, kita menyaksikan skenario di mana banyak perempuan bekerja baik di sektor resmi maupun informal. Bagi sebagian yang lain, mungkin ada anggapan bahwa sedang terjadi sesuatu yang bertentangan dengan konstruksi gender konvensional Indonesia, bahwa tugas perempuan hanya sebatas mengurus rumah tangga, atau yang populer disebut sebagai pekerjaan rumah tangga (Oetomo, 2006). Sebagai masyarakat demokratis, pilihan orang yang mencari pekerjaan, baik laki-laki maupun perempuan, harus menjadi hak asasi manusia yang fundamental. Namun karena struktur gender yang seksis, perempuan seringkali didomestikasi (Hadi, 2016). Kemudian, bahkan setelah perempuan mendapatkan akses untuk bekerja, mereka terus menghadapi diskriminasi di tempat kerja. Misalnya, seperti terungkap dalam Sakernas 2019, upah perempuan 23 persen lebih rendah dari laki-laki, posisi masih didominasi laki-laki (69,37 persen), dan perlindungan kerja yang tidak memadai, sehingga 
menjadi pihak yang rentan terhadap kekerasan, khususnya di sektor informal (Khotimah, 2009).

Kesetaraan gender merupakan masalah global yang terus menjadi penting di berbagai bidang saat ini. Di sektor ekonomi, misalnya, ada topik sensitif Gender Pay Gap, atau disparitas gaji antara laki-laki dan perempuan. Laki-laki sering diberi kompensasi lebih dari perempuan selama tahun-tahun produktif mereka (Blau \& Kahn, 1999). Menurut American Association of University Women, wanita yang bekerja penuh waktu di Amerika Serikat biasanya berpenghasilan kurang dari $80 \%$ dari penghasilan pria. Perempuan diantisipasi untuk mencapai kesetaraan upah dengan laki-laki pada tahun 2059, berdasarkan pola pengembangan kesetaraan upah antara tahun 1960 dan 2016. Namun, jika tren saat ini berlanjut pada kecepatan mereka saat ini, perempuan tidak akan mencapai kesetaraan dengan laki-laki sampai tahun 2119.

Gender adalah subjek yang sangat rumit untuk dieksplorasi karena terkait dengan konteks sosial, budaya, ekonomi, dan politik yang ditekankan oleh semua orang. Gender adalah perbedaan yang diciptakan secara sosial antara pria dan wanita, sedangkan gender adalah perbedaan biologis. Disparitas gender diciptakan secara sosial dan dipengaruhi oleh faktor-faktor seperti usia, status perkawinan, agama, asal suku, budaya, ras, dan kelas/kasta (Rokhmansyah, 2016).

Artikel ini berfokus pada kesetaraan perekrutan tenaga kerja, khususnya tentang kurangnya perempuan dalam posisi manajemen. Ada mitos lama atau persepsi yang salah tentang perbedaan dalam gaya kerja, gaya manajemen dan sikap laki-laki dan perempuan, yang di suatu tempat dapat ditemukan setia karena sifat-sifat yang melekat terkait gender. Selain itu, dalam banyak kasus, perempuan dianggap kurang tersedia. untuk posisi manajemen yang lebih tinggi dalam organisasi. Literatur kontemporer penuh dengan teknik self-help untuk membuat wanita mengatasi kekurangan yang melekat pada menjadi wanita (Sumantri dkk., 2013). Ada juga beberapa tips yang diberikan oleh peneliti untuk membantu wanita berhasil dalam permainan perusahaan dengan strategi untuk meningkatkan kemampuan dalam hal meningkatkan gaya komunikasi, mengarahkan keterampilan dan prospek karir jangka panjang. Sebagian besar penulis ini menyatakan bahwa membawa perempuan ke tempat kerja adalah kelemahan yang menghambat kemajuan dan kelemahan yang harus diatasi perempuan untuk berhasil (Wibowo, 2012).

Fakta bahwa perempuan memiliki gaya kerja manajemen yang berbeda dari laki-laki tidak dapat menjelaskan bahwa posisi manajemen puncak tidak dimiliki oleh perempuan. Dengan demikian, argumen bahwa perempuan tidak dapat memainkan peran yang menantang dari manajemen senior karena mereka kurang sehat dalam keterampilan atau temperamen membuat keterwakilan perempuan saat ini di tingkat tinggi adalah adil dan merata, memang sangat mencurigakan.

\section{B. METODE}

Penelitian tentang kesenjangan gender dan kesetaraan di tempat kerja menggunakan pendekatan kualitatif dengan pengumpulan sumber data dengan metode studi kepustakaan. Penelitian kualitatif adalah suatu pendekatan studi untuk mengkaji dan memahami makna individu atau kelompok tertentu yang berasal dari masalah sosial atau manusia (Creswell, 2013). Laporan akhir studi kualitatif memiliki format yang fleksibel. Pendekatan penelitian 
ini adalah tipe induktif, berfokus pada makna individu, dan mengkomunikasikan kompleksitas suatu masalah. Penelitian kualitatif dimulai di lapangan berbasis lingkungan alam, bukan teori. Fakta dan informasi yang dikumpulkan dari lapangan diambil untuk makna dan konsep, disajikan dalam gaya deskriptif analitis dan biasanya tanpa menggunakan angka karena mengutamakan proses yang terjadi di lapangan.

\section{HASIL DAN PEMBAHASAN}

Kesetaraan tempat kerja tidak terdiri dari mentransfer hak istimewa kepada perempuan dan merampas laki-laki dari kelompok tradisional bebas, hak eksklusif, tetapi mengambil semua bentuk diskriminasi daripada memindahkan dominasi dari laki-laki ke perempuan. Ini dianggap sebagai proses penghilangan dominasi. Kesetaraan di tempat kerja menganggap perempuan memenuhi syarat sebagai laki-laki (Astuti, 2018). Kesetaraan tidak berarti bahwa perempuan berusaha untuk menaikkan level promosi mereka, tetapi tidak memaksa mereka untuk melakukan promosi yang tidak pantas. Kesetaraan tempat kerja untuk organisasi harus mengharapkan untuk memiliki tenaga kerja yang lebih mewakili campuran seimbang baik gender dan citra adil dari komunitas yang mereka layani karena masuk akal bisnis yang baik (Russell \& Eby, 1993). Ini juga berarti bahwa siapa pun yang gagal mendapatkan pekerjaan mendapat hukuman yang sama dengan orang lain. Dalam bentuk apapun, organisasi tidak dapat menerima sistem insentif yang didasarkan pada jenis kelamin karyawan.

Ada beberapa hal yang mnyebabkan munculnya ketidakseimbangan dalam kesetaraan gender di tempat kerja yaitu antara lain:

1. Stereotip Jenis Kelamin

Stereotip adalah sekumpulan atribut yang dimiliki oleh suatu kelompok, yang diyakini mencirikan anggotanya hanya karena mereka termasuk dalam kelompok tersebut. Dalam kasus stereotip seksual, atribut melekat pada laki-laki dan perempuan berdasarkan jenis kelamin atau gender mereka. Sifat dan karakteristik yang terkait dengan pria dan wanita berbeda, tetapi mereka juga memiliki nilai yang berbeda. Meskipun diyakini bahwa setiap orang memiliki sifat yang diinginkan, dan sebagian besar menyatakan bahwa sifat laki-laki lebih unggul dibandingkan dengan perempuan dan minoritas. Perempuan cenderung menderita stigma anggota asing dari organisasi sebagai akibat dari perlakuan istimewa terhadap kelompok dominan, dan juga menderita ideologi bahwa perempuan tidak dipekerjakan berdasarkan kualifikasi mereka tetapi diperkirakan dipekerjakan untuk jenis kelamin atau ras mereka (Aslichati, 2011). Meskipun berhasil, para perempuan ini tidak diperlakukan sebagai teladan dan mentor yang dapat diandalkan bagi perempuan lain karena mereka tampaknya memperoleh kesuksesan dengan mengadopsi gaya kerja dan mencerminkan ciri-ciri kelompok dominan, yaitu laki-laki. Perempuan dapat memiliki pengalaman kerja sendiri berdasarkan identitas dan karakteristik pekerjaannya. Ini juga mengakui bagaimana pengalamannya dibentuk oleh proses persepsi dan interpretasi interaktif yang menghubungkannya dengan lingkungannya.

2. Pelecehan seksual

Pelecehan seksual terhadap perempuan juga terkait dengan representasi mereka yang lebih rendah terutama mempertimbangkan pelecehan di tempat kerja. Karena sebagian besar perempuan dilecehkan dan laki-laki adalah pelaku utama, tetapi juga tidak mengherankan 
bahwa perempuan lebih cenderung lebih sensitif terhadap kekhawatiran tentang pelecehan seksual. Wanita menemukan diri mereka lebih mungkin dilecehkan ketika pindah ke posisi manajemen yang lebih tinggi atau area non-tradisional dalam organisasi (Schneer \& Reitman, 1995). Perilaku ramah perempuan kadang-kadang bahkan secara keliru dianggap sebagai masalah seksual. Meskipun pria menilai tingkat keparahan perilaku ini lebih banyak daripada wanita, wanita cenderung percaya bahwa pria meremehkan tingkat keparahan jenis pelecehan yang khas. Telah ditunjukkan oleh para peneliti bahwa wanita menjadi lebih menguntungkan. Ketika organisasi memposting posisi yang kosong, secara khusus tanyakan dan berikan preferensi kepada kandidat wanita (dan kelompok non-tradisional lainnya) dan mungkin berdebat dengan cara bahwa perusahaan telah menjanjikan kesetaraan pekerjaan (Priyadi \& Astuti, 2003). Laki-laki sekarang merasakan perubahan dalam pola demografi tenaga kerja, meskipun belum langsung ditolak tetapi mungkin segera menjadi minoritas. Lebih jauh lagi, jika mereka melihat statistik dengan cermat, perempuan perlahan tapi pasti lewat, dan bahkan mereka bisa mendapatkan alasan. Kami menemukan bahwa di sebagian besar situs survei dan konsultasi, pria yang mendapatkan promosi sekarang lebih banyak daripada wanita, tetapi persentase wanita yang telah menerima promosi dalam beberapa tahun terakhir telah meningkat lebih cepat daripada tingkat pria. Beberapa pria sekarang sadar bahwa dunia sekitarnya menjadi lebih kompetitif. Pria sebelumnya hanya berkompetisi dengan pria lain; sekarang, laki-laki juga menghadapi persaingan dari perempuan.

3. Dominasi pria

Dominasi mempengaruhi semua orang tanpa memandang gender wanita, pria, dan bahkan organisasi. Dominasi Pria mempengaruhi hubungan antara pria dan wanita, sehingga meningkatkan ketegangan di antara mereka. Dominasi Pria mendukung pandangan beberapa wanita tentang beberapa sikap Neanderthal pria. Pria-pria ini "tidak mengerti" dan wanita dapat memandang mereka sebagai musuh. Dominasi Pria memperkuat ikatan antara beberapa pria. Pria merasa sebagai spesies yang terkepung dan terancam punah. Sekarang mereka didiskriminasi. Durasi waktu ini menekankan skeptisisme, ambivalensi, perubahan konstan dan serangan terhadap identitas dan dominasi laki-laki (Fajrin \& Susilo, 2018). Era ini telah mendorong batas-batas karir tradisional. Aturan laki-laki juga mempengaruhi organisasi dalam berbagai metode konyol. Banyak energi dapat terkuras dalam ketegangan, kemarahan, dendam, dan frustrasi. Laki-laki mungkin dikalahkan oleh upaya sistematis untuk mendukung karir perempuan. Para peneliti telah menemukan bahwa dominasi terdaftar sebagai perhatian utama yang dihadapi oleh organisasi dalam mendukung dan mempromosikan karyawan perempuan dan kelompok minoritas lainnya.

4. Glass ceiling

Apakah jabatan direksi hanya diperuntukkan bagi calon laki-laki? Selain itu, faktorfaktor apa yang menentukan bahwa pandangan perempuan akan ditolak sepenuhnya untuk diangkat pada posisi manajemen senior? "Plafon Kaca" berarti seberapa banyak perempuan dapat pindah ke hierarki status perusahaan. Seleksi perempuan harus didasarkan pada prestasi, dan prinsip nilai ini tampaknya lebih efektif dalam merekrut perempuan dan membuat mereka maju, tetapi jika prinsip ini berpihak pada laki-laki, maka organisasi akan mendiskriminasi perempuan. Tidak sulit untuk mengasumsikan rendahnya representasi perempuan dalam organisasi dan industri yang didominasi laki-laki (Cotter dkk, 2001). Karena kurangnya perempuan yang layak dan terampil, perempuan memiliki pilihan untuk 
bekerja dari banyak perusahaan. Penelitian lebih lanjut juga menunjukkan bahwa harga saham perusahaan dan tanggal pemilihan direktur wanita tercermin secara positif.

Agar poin-poin tersebut tidak terjadi pada lingkungan kerja maka perlu diambil langkah-langkah untuk menciptakan dan menjaga keseimbangan ketenagakerjaan. Langkahlangkah tersebut antara lain:

\section{Memotivasi Diri Sendiri}

"Wanita hanya bisa berharap untuk menjadi sebaik pria, dan tidak masuk akal untuk mencoba". Selain itu, struktur sosial saat ini di banyak organisasi ditandai dengan menekankan objektivitas. Dalam kompetisi, hanya ada satu aturan "bekerja di tempat kerja". Wajar jika terbuka dan kontradiktif. Hal ini umumnya dianggap bahwa manajer kompetitif, logis, rasional, tegas, ambisius, agar efisien, berorientasi pada hasil, dan bertenaga hasil dan percaya diri dalam penggunaan klaim dan kekuasaan, perlu berkomitmen untuk mengejar tujuan organisasi. Konsistensi dalam penerapan standar universal adalah hal mendasar, seperti halnya penghormatan terhadap sistem komando dalam hierarki organisasi. Faktor luar (misalnya, janji peran keluarga) dianggap tidak material bagi budaya kerja dalam organisasi dan harus disegmentasi untuk menghindari menghambat kinerja pekerjaa (Shaleh \& Firman, 2018). Haruskah perempuan "berperilaku seperti laki-laki" (mengapa)? Tujuan yang tidak diumumkan mungkin adalah kemajuan organisasi. Selain itu, dalam hal ini, agar laki-laki dan perempuan dapat diterima secara umum, maskulinitas perusahaan perlu diakui sebagai eksekutif bisnis, yaitu untuk berhasil dan maju.

Mendorong perempuan di puncak manajemen organisasi adalah untuk memberikan perasaan organisasi bahwa perempuan harus menjadi bagian dari organisasi, poin-poin ini meliputi: otoritas demokratis, kesetaraan dan pembagian kerja, pemimpin sebagai koordinator dan fasilitator, berbagi pengetahuan dan keterampilan, hubungan antara pekerjaan mental dan manual, peran dan peristiwa yang terintegrasi dan terhubung (Sasmita \& Raihan, 2014). Tujuan numerik adalah standar yang ditetapkan oleh organisasi dan membentuk dasar untuk menilai apakah perempuan dan kelompok minoritas lainnya dinilai sama dalam memilih kandidat terbaik dan dalam keputusan promosi. Kuota adalah rasio numerik yang ditetapkan dan diterapkan oleh pemerintah dan merupakan dasar pengakuan bahwa lebih penting untuk membuat asumsi berdasarkan status minoritas daripada standar praktik yang relevan. Sebaliknya, keputusan seleksi dan promosi masih berbasis gender, termasuk dalam jaringan konservatif dan memiliki bukti substansial bahwa keputusan tersebut tidak didasarkan pada prestasi.

\section{Arus Informasi yang Lancar}

Aliran informasi yang tepat merupakan langkah penting karena semua bentuk diskriminasi menghancurkan diri mereka sendiri dalam sistem pasar, tetapi diskriminasi gender tidak menanggapi kekuatan pasar. Pasar mungkin memiliki kekuatan kuat yang bekerja untuk menghapus diskriminasi gender, tetapi kemampuan lain yang lebih kuat memperburuknya. Akibatnya, sulit untuk mengukur efektivitas program ketenagakerjaan yang tepat jika kekuatan untuk bertindak mendukung diskriminasi tidak dipahami oleh organisasi (Zuhaena \& Masita, 2015).

Salah satu hambatan utama untuk mengekang diskriminasi adalah kurangnya informasi yang tepat dan relevan, valid tentang pekerjaan dan potensi anggota organisasi. Pasar efisien hanya jika ada arus informasi yang tidak terputus, jadi jika suatu organisasi 
tidak dapat menghasilkan informasi yang akurat dan akurat tentang seorang individu atau sekelompok pekerja, kekuatan pasar tidak dapat menghilangkan diskriminasi. Keputusan pekerjaan jarang didasarkan pada "keputusan data-objektif," melainkan sangat bergantung pada perilaku budaya, politik dan sosial kehidupan organisasi. Dengan tidak adanya informasi yang objektif dan valid tentang kinerja dan potensi seseorang, pembuat keputusan mengandalkan referensi dan rekomendasi langsung dari platform yang kredibel (Pattipawae, 2011).

Oleh karena itu, sejumlah besar keputusan perekrutan karyawan diambil berdasarkan informasi yang dikomunikasikan melalui jaringan informal. Karena sebagian besar pengambil keputusan adalah laki-laki dan aktif dalam jaringan laki-laki mereka sendiri, informasi yang disampaikan melalui sistem alami biasanya dikonstruksi sedemikian rupa sehingga membuat perempuan tidak beruntung. Situasi saat ini berarti bahwa bagi perempuan, informasi yang relevan dan valid tentang kinerja dan kemampuan mereka ditransmisikan melalui jaringan informal, dan sistem sosial, politik dan sosial tidak membatasi transmisi informasi yang tepat tentang kemampuan dan keterampilan mereka untuk mengembangkan strategi baru.

Di bidang budaya, kendala kritis terhadap informasi akurat yang diperhitungkan dalam keputusan pekerjaan adalah stereotip seks yang tidak tepat. Lima mitos berikut ini banyak ditemukan wanita mandiri. a) Wanita terlalu muda atau terlalu tua untuk dipromosikan. b) Wanita akan memiliki bayi dan berhenti. c) Perempuan membutuhkan pendidikan tinggi. d) Wanita tidak memiliki "barang yang benar". e) Wanita segera menikah.

\section{Intervensi Pemerintah}

Saat ini, penulis menganjurkan pendekatan pengaturan mandiri yang dimodifikasi yang melanjutkan peran pemerintah sebagai legislator. Namun, yang menjadi pusat perhatian pemerintah adalah sosialisasi dan edukasi. Pergeseran bagian dari pembelajaran dan konsultan memungkinkan pemerintah untuk fokus pada perubahan sikap terhadap program kerja dan meningkatkan peran perempuan dalam angkatan kerja. Lebih jauh lagi, berkurangnya fungsi 'saudara' memungkinkan pemerintah untuk mempengaruhi kebijakan sosial secara lebih efektif, sementara pada saat yang sama memungkinkan organisasi untuk memutuskan bagaimana mencapai tujuan sosial yang lebih luas. Agar pengaturan mandiri menjadi efektif, pemerintah perlu mengintensifkan upaya mereka untuk membentuk sikap mereka terhadap keadilan kerja dan membentuk definisi standar dan standar yang jelas untuk mengukur keadilan. Organisasi, di sisi lain, perlu meningkatkan peran karyawan dalam perencanaan dan implementasi dan mengembangkan sistem 'pengaturan mandiri yang dipaksakan'.

Aturan dan peraturan pemerintah harus memperhatikan modal kerja (angka), kehadiran inisiatif, dukungan untuk karir perempuan, motivasi untuk memulai program tersebut, kredibilitas manajemen senior pada isu-isu kesetaraan, pendidikan, keterampilan karyawan dan, jumlah dan lokasi perempuan dalam organisasi, kehadiran perempuan dalam organisasi (Ulya, 2018). Faktor sosiologis prediktif untuk Dominasi laki-laki termasuk visibilitas isu-isu kesetaraan di kalangan masyarakat umum, visibilitas gejala dominan lakilaki di depan umum, dan jumlah dan relevansi peristiwa yang merayakan hasil Perjuangan Perempuan Termasuk Aspek Makroekonomi juga. 


\section{Mengubah Perspektif tentang Kesetaraan Kerja}

Persepsi yang berlawanan dan negatif tentang program kesetaraan pekerjaan terbuka tersebar luas di antara organisasi, dan persepsi ini membentuk skenario yang hampir mustahil bagi sebagian besar organisasi yang tertarik pada lingkungan kerja yang bersih dan adil. Program kesetaraan pekerjaan sering dipersalahkan sebagai "penutup jendela" karena pengakuan bahwa program tersebut telah membawa perubahan estetika tanpa reformasi menyeluruh yang adil. Masalah ini sering muncul dari pendekatan "top down" yang tidak dapat menghubungkan proses pengambilan keputusan dengan implementasi dan penilaian. Dalam banyak kasus, setelah kebijakan kesetaraan ketenagakerjaan dirumuskan, manajemen puncak beralih ke masalah yang lebih mendesak dan mengambil pendekatan yang tidak mengikat. Karyawan tingkat rendah yang tidak berpartisipasi dalam proses perencanaan dan dengan demikian tidak memahami arti dan orientasi yang benar yang dimaksudkan oleh manajemen dan menghadapi masalah dalam implementasi, penerapan, resolusi konflik, dan pembelajaran (Wahyudi, 2013).

Maka jelas dan wajar bahwa mereka yang bertanggung jawab untuk menerapkan kebijakan ketenagakerjaan yang adil merasa terancam oleh rencana tersebut dan mengabaikan atau menyabotnya. Dengan demikian, langkah pertama dalam sistem pengaturan mandiri organisasi yang direvisi adalah memahami persepsi dan sikap saat ini tentang kesetaraan dalam lingkungan tertentu. Setelah menetapkan dasar sikap umum, identifikasi tindakan yang diperlukan untuk mengubah sikap tersebut dari yang menghasilkan definisi stereotip negatif ke tindakan yang membangun dan membentuk struktur keadilan dan kesetaraan. Itu menjadi tanggung jawab masing-masing organisasi. Langkah-langkah utama perlu dikumpulkan, semua langkah lebih lanjut dalam sistem pengaturan mandiri akan lebih baik dilayani oleh partisipasi dan kemungkinan keterlibatan anggota organisasi.

Program keamanan karyawan tidak boleh dianggap atau diterima sebagai kewajiban eksklusif. Berdasarkan sifat pekerjaan, ini adalah ketidaksetaraan petualangan, dan memiliki peluang sukses yang paling baik ketika berurusan dengan semua orang yang terpengaruh olehnya secara setara.

\section{KESIMPULAN}

Agar kesetaraan pekerjaan atau kesetaraan tempat kerja benar-benar bermanfaat, kita perlu fokus pada mengubah stereotip gender yang tidak tepat dan mengubah sikap saat ini terhadap perempuan di tempat kerja. Penting untuk mengembangkan program komunikasi penting untuk melawan tren ketidakadilan hanya dalam rencana stok karyawan. Kita perlu secara teratur memperkuat pesan bahwa kesetaraan profesional secara tegas didasarkan pada penerapan prinsip jasa. Untuk mendidik anggota organisasi tentang keberadaan mereka dan memastikan bahwa praktik tersebut tidak termasuk dalam kebijakan dan prosedur baru, sehingga perlu untuk menghindari diskriminasi sistematis yang melekat pada sistem saat ini. Jika karyawan terlibat dalam pengembangan dan implementasi rencana stok, mereka kemungkinan besar akan mendukung dan mempertimbangkan program ketenagakerjaan sebagai hal yang adil dan tidak mungkin mengarah pada kontra-diskriminasi. 


\section{DAFTAR PUSTAKA}

Aslichati, L. (2011). Organisasi Pemberdayaan dan Kesejahteraan Keluarga Sebagai Sarana Pemberdayaan Perempuan. Jurnal Organisasi dan Manajemen, 7(1), 1-7.

Astuti, I. Y. (2018). Perbedaan Motivasi Belajar Warga Belajar Perempuan dan Laki-Laki dalam Mengikuti Pendidikan Kesetaraan Paket C. Journal of Nonformal Education and Community Empowerment, 2(1).

Blau, F. D., \& Kahn, L. M. (1999). Analyzing The Gender Pay Gap. The Quarterly Review of Economics and Finance, 39(5), 625-646.

Cotter, D. A., Hermsen, J. M., Ovadia, S., \& Vanneman, R. (2001). The glass ceiling effect. Social forces, 80(2), 655-681.

Creswell, J. W. (2013). Metode Penelitian Kuantitatif, Kualitatif, dan Campuran. Yogyakarta: Pustaka Pelajar.

Fajrin, I. Q., \& Susilo, H. (2018). Pengaruh Gaya Kepemimpinan Terhadap Kinerja Karyawan Dengan Motivasi Kerja Sebagai Variabel Intervening (Studi pada Karyawan Pabrik Gula Kebon Agung Malang). Jurnal Administrasi Bisnis, 61(4), 117-124.

Hadi, S. (2016). Bias Gender dalam Konstruksi Hukum islam di indonesia. PALASTREN Jurnal Studi Gender, 7(1), 25-46.

Khotimah, K. (2009). Diskriminasi Gender terhadap Perempuan dalam Sektor Pekerjaan. Yinyang: Jurnal Studi Islam Gender dan Anak, 4(1), 158-180.

Oetomo, D. (2006). Memperjuangkan Hak Asasi Manusia Berdasarkan Identitas Gender dan Seksualitas di Indonesia. Semiloka Hak atas Kebebasan Pribadi bagi Kelompok Lesbian, Gay, Biseksual, Interseksual, Transgender, dan Transeksual, 15-16.

Pattipawae, D. R. (2011). Penerapan Nilai-Nilai Dasar Budaya Kerja dan Prinsip-Prinsip Organisasi Budaya Kerja Pemerintah dengan Baik dan Benar. Sasi, 17(3), 31-44.

Priyadi, U., \& Astuti, B. (2003). Tingkat Kesetaraan Gender Ingkat Kesetaraan Gender Pada Industri Kulit Di Propinsi Daerah Istimewa Yogayakarta. Economic Journal of Emerging Markets, 8(1).

Rokhmansyah, A. (2016). Pengantar Gender Dan Feminisme: Pemahaman Awal Kritik Sastra Feminisme. Garudhawaca.

Russell, J. E., \& Eby, L. T. (1993). Career Assessment Strategies for Women in Management. Journal Of Career Assessment, 1(3), 267-293.

Sasmita, J., \& Raihan, S. A. A. (2014). Kepemimpinan Pria dan Wanita. Pekanberu: Unri.

Schneer, J. A., \& Reitman, F. (1995). The Impact of Gender as Managerial Careers Unfold. Journal of Vocational Behavior, 47(3), 290-315.

Shaleh, M., \& Firman, S. P. (2018). Komitmen Organisasi Terhadap Kinerja Pegawai. Penerbit Aksara Timur.

Sumantri, B., Fariyanti, A., \& Winandi, R. (2013). Faktor-Faktor Yang Berpengaruh Terhadap Kinerja Usaha Wirausaha Wanita: Suatu Studi Pada Industri Pangan Rumahan di Bogor. Jurnal Manajemen Teknologi, 12(3), 252-277.

Ulya, I. (2018). Pendidikan Berbasis Kesetaraan Gender: Studi Kebijakan Pemerintah dan Aplikasinya dalam Pendidikan. MAGISTRA: Media Pengembangan Ilmu Pendidikan Dasar dan Keislaman, 4(1), 11-32.

Wahyudi, J. (2013). Analisis Persepsi Mahasiswa Akuntansi Atas Reward, Pelatihan Profesional, Nilai Sosial, Lingkungan Kerja, Pertimbangan Pasar Kerja, Personalitas Dan Kesetaraan Gender Terhadap Pemilihan Karir Sebagai (Doctoral dissertation).

Wibowo, D. E. (2012). Peran Ganda Perempuan Dan Kesetaraan Gender. Muwazah: Jurnal Kajian Gender, 3(1). 
Zuhaena, F., \& Masita, T. E. (2015). Manajemen Co-Determination Berbasis Gender Dalam Sistem Perburuhan Di Indonesia. Jurnal Riset Manajemen Sekolah Tinggi Ilmu Ekonomi Widya Wiwaha Program Magister Manajemen, 2(2), 141-154. 